University of Northern lowa

UNI ScholarWorks

Faculty Publications

Faculty Work

$12-2016$

\title{
Cross-Language Community Engagement: Assessing the Strengths of Heritage Learners
}

\author{
Elise DuBord \\ University of Northern lowa \\ Elizabeth Kimball \\ Drew University
}

Let us know how access to this document benefits you

Copyright (C2016 Elise DuBord and Elizabeth Kimball

Follow this and additional works at: https://scholarworks.uni.edu/ll_facpub

Part of the Modern Languages Commons, and the Modern Literature Commons

\section{Recommended Citation}

DuBord, Elise and Kimball, Elizabeth, "Cross-Language Community Engagement: Assessing the Strengths of Heritage Learners" (2016). Faculty Publications. 1.

https://scholarworks.uni.edu/ll_facpub/1

This Article is brought to you for free and open access by the Faculty Work at UNI ScholarWorks. It has been accepted for inclusion in Faculty Publications by an authorized administrator of UNI ScholarWorks. For more information, please contact scholarworks@uni.edu. 


\title{
Cross-Language Community Engagement: Assessing the Strengths of Heritage Learners
}

\author{
Elise DuBord \\ University of Northern Iowa \\ Elizabeth Kimball \\ Drew University
}

\begin{abstract}
This article reports on university students' learning outcomes stemming from their work as language partners in a community-based learning project in an English for Speakers of Other Languages (ESOL) class with adult Spanish-speaking immigrants. We present a rubric designed to assess student learning in the collaborative, cross-language nature of the partnership that moves beyond notions of language acquisition. The rubric was used to score the reflective writing of students in two university classes who participated in this off-campus partnership, one in Spanish for majors, and one in English for general education students. Our analysis focuses on correlations between students' language backgrounds and previous service experiences and the kinds of learning they experienced, in order to explore the strengths that different kinds of students bring to community work. Heritage learners in both university classes achieved the highest outcomes, and they did so regardless of whether they were heritage learners of Spanish or other languages. Students with low levels of previous community engagement - many of whom were students of color and/or heritage learners - also had higher outcomes than their peers with higher levels of previous community engagement. We argue that inclusive project design and local, critical assessment of student outcomes in community-based learning can foster constructive partnerships that recognize and build upon the strengths of heritage learners.
\end{abstract}

Keywords: assessment of student learning, critical service-learning, cross-language partnership, heritage learners, translingualism

\section{INTRODUCTION}

Much of the literature on community-based learning (CBL), ${ }^{1}$ including that within the field of Spanish, has described and theorized programs assuming that college students are white, middleclass, native speakers of English. The expectation is often that university students in these CBL classes will be exposed to Spanish in the real world and real Spanish speakers in their communities in ways they cannot in the classroom. However, students in college-level Spanish classes have a wide range of language backgrounds and familiarity with community settings, all of which merit careful consideration in project planning and assessment. Local community settings are more than convenient alternatives to study abroad for university language students; they often result in productive opportunities for collaboration with community members and allow a range of students to make connections between the skills and proficiencies they have developed in- and outside of academia. 
The present study explores university students' outcomes in a CBL project where students in Spanish and English classes at Drew University were tutors in classes in English for Speakers of Other Languages (ESOL) at a historic immigrant settlement house in northern New Jersey. Our community partners were Spanish-speaking immigrants from Latin America. The adults who were learning English in this community setting were diverse in terms of their length of time in the U.S., country of origin, age, educational background, and English proficiency. The university students who participated in the project likewise had diverse ethnolinguistic and educational backgrounds, including home environments where Chinese, English, Italian, Portuguese, and/or Spanish were spoken. Many students were studying Spanish (as a second, third, or heritage language) or another language other than English, while others were essentially English monolinguals who were not pursuing language study beyond the three semesters required of our degree program. Students also had varying amounts of previous experience with community service. Students from white, monolingual, English-speaking backgrounds claimed higher levels of previous service experience than their peers who were people of color and/or multilingual.

Our analysis of this project takes as its starting point what Leeman (2011) calls "critical service learning" in language programs "that seek to develop community-university partnerships to address community needs while also engaging students in critical analysis of sociopolitical issues linked to language" (p. 303). This article will first frame our assessment of this cross-language collaboration by taking into account the history and culture of community service, particularly in reference to language learning pedagogies and ideologies that emerge in relation to heritage learners. After describing the participants and research setting, we present a rubric for the

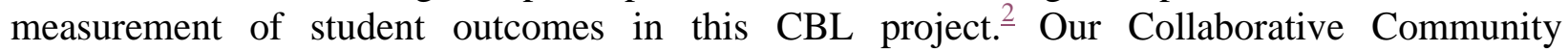
Engagement Rubric (see Appendix) is a locally-tailored, adaptable tool for assessing student outcomes in community settings. The rubric was designed intentionally to localize and complicate the more general learning outcomes of both language curricula (such as ACTFL's 5 Cs) and civic engagement programs, in order to identify the contours of learning that were taking place in our context.

Our analysis of student outcomes based on this rubric reveals that ethnolinguistic minority students achieved higher outcomes in key areas, suggesting that they are able to successfully apply valuable language and interpersonal skills to community projects. In particular, heritage learners (HLs) achieved the highest scores in the categories of Dialogic Communication and Problem Solving, and they did so regardless of whether they were HLs of Spanish or other languages, confirming the results of Leeman, Rabin \& Román-Mendoza (2011), whose research demonstrates HLs' gains in critical service-learning, not only in their linguistic abilities, but also through their embodiment as language experts in ways that contest deficient models of HLs. In fact, it is these students who provided the leadership and modeling of the "translingual approach" (Horner, Lu, Royster, \& Trimbur, 2011) to communication that is necessary in diverse contexts. Horner et al. write that " $[t]$ his approach sees difference in language not as a barrier to overcome or as a problem to manage, but as a resource for producing meaning in writing, speaking, reading, and listening" (p. 303). It is more "about the disposition of openness and inquiry that people take toward language and language differences" (p. 311), than any one individual's 
multilingual prowess. Because the language proficiencies in both English and Spanish of our university and community students varied so widely, this translingual disposition was essential to creating productive and positive experiences for all.

If we had assessed these students' learning against more typical outcomes, such as those rooted in mastery of academic knowledge, or their acclimation to the white, monolingual, middle-class norms of community service - in which a student enters a service site outside of their own community, performs a task, reflects on it, and is rewarded for crossing a cultural boundarythese students' achievements would not have been as apparent.

Despite intensive efforts to create engaged and experiential learning opportunities in higher education, institutional structures and expectations often silence the strengths that HLs bring to the classroom. Although they regularly receive less recognition for their linguistic, cultural, and social capital (Zentella, 2003; Urciuoli, 2008), many minority students are positioned to excel in community settings even if universities are not always prepared to design community partnerships that acknowledge or build on their strengths. As CBL practitioners, we must continually strive to facilitate learning environments that value the skills of all students and intentionally build on their skills in productive ways in the community. We argue that this kind of local assessment, as presented in the Collaborative Community Engagement Rubric, can foster more inclusive and successful partnerships, particularly in ways that make the most of the gifts of language heritage.

\section{LITERATURE REVIEW}

This study adopts a critical approach to CBL—what Mitchell (2008) describes as "dismantl[ing] structures of injustice" (p. 50). Such an approach demands a similarly critical attitude towards assessment, which seeks to uncover assumptions about student learning that may be rooted in assimilationist, English monolingual, or other ideologies that erase difference. Such an approach requires that the instruments of assessment be scrutinized with the same care that student work is examined, and recognizes that learning is tentative, emergent, and local (Hussey \& Smith, 2008; Gallagher, 2012; Broad, 2003). Numerous studies have documented the (usually) positive effects of CBL on student learning outcomes, but they rely on published instruments that measure predetermined outcomes (Molee, Henry, Sessa, \& McKinney-Prupis, 2010; De Leon, 2014; Pedersen, Mayer, \& Hargrave, 2015). Locally designed assessment instruments may help us discover and build on student strengths that are hidden by generalized instruments, especially those strengths possessed by students from underrepresented groups. The following discussion provides a more detailed overview of the research that emerges from this critical approach and then examines the explicitly translingual framework that we have adopted for this project.

\section{Community-based Learning in Spanish}

As the field of community-based learning emerged in Spanish and other languages, much of the early literature described and reflected on project implementation (cf. Hellebrandt \& Varona, 1999; Hellebrandt, Arries, \& Varona, 2003) and relies on research warrants from research from the broader service-learning movement that demonstrates its benefits for increased student 
engagement, civic awareness, and life skills (Beebe \& De Costa, 1993; Nelson \& Scott, 2008). Numerous studies have demonstrated the power of service learning in general to increase student learning (Eyler, Giles Jr., Stenson, \& Gray, 2001) and in a meta study of several articles, Novak, Markey, and Allen (2007) found that participation in service-learning increased students' overall scoring above the median on learning outcomes by $50 \%$, mainly in the area of understanding of course material. The evaluation of student outcomes has been a persistent theme in the literature on CBL, particularly because of CBL's recent emergence and frequent resistance to it in the disciplines, in addition to the strong pull for assessment across higher education.

Over time, questions related to the teaching and learning of a new language have been addressed, more specifically, on the effect of CBL on language acquisition (Overfield, 1997; Mullaney, 1999). Frequently, researchers make a point of claiming second language acquisition (SLA) gains among Spanish students through their service work, particularly in terms of motivation (Nelson \& Scott, 2008; Beebe \& De Costa, 1993; Morris, 2001; Weldon \& Trautmann, 2003) and confidence (Olazagasti-Segovia, 2003; Zapata, 2011).

Alternatively, other studies minimize the question of direct language acquisition and claim that other kinds of learning outcomes are more important. In these studies, the American Council on the Teaching of Foreign Languages (ACTFL)'s "5 Cs" (Communication, Cultures, Connections, Comparisons, and Communities) have played a key role in framing the argument. Scholars of service-learning frequently cite the "community" aspect as having been underutilized in language classes generally, while "communication" has been privileged in the literature (Hale, 1999; Plann, 2002; Tilley-Lubbs, Raschio, Jorge, \& López, 2005). ${ }^{3}$ Tilley-Lubbs (2007) goes so far as to say that any aspect of language learning is secondary to service-learning in general, where success "lay in the relationships described by both students and community participants, NOT in acquiring linguistic or cultural knowledge" (p. 301; see also Hellebrandt \& Varona, 1999). Pellettieri's (2011) results, using her Willingness to Communicate instrument, reveal a gap between students who succeed as communicators in a language inside the classroom and those who succeed outside of it. Her results affirm our findings that the community setting teaches skills that are not generally measured in academic settings.

For both HLs and L2 learners, research suggests that cultural competence and making community connections are of greater value than narrowly defined language gains in CBL. However, our review of the literature reveals an underlying tension between linguistic acquisition and the other "soft" interpersonal and intercultural skills that accompany it, which will not be resolved easily. Indeed, both linguistic competence and cultural and community connections are an essential part of the 5 C's. But because linguistic outcomes are often either held up as a promise, or minimized as secondary to broader cultural learning, these studies point to the need to theorize cross-language CBL in ways that draw from more sophisticated models of language learning in which the shared natures of language and culture are better understood. In the translingual model that we draw on here, language is built by the people using it together; foundational notions of recognizable named languages, such as English and Spanish, must be 
discarded (Otheguy, García, \& Reid, 2015). The instrument we present here draws from these translingual models.

\section{CBL and Heritage Learners}

The presence of heritage learners complicates the foundational assumptions of the 5 C's in particularly urgent ways. These assumptions become visible in the research that seeks to embrace ethnolinguistic diversity among students as the $5 \mathrm{C}$ 's clearly recommends, yet runs into a roadblock when assessing student learning. For example, although Barreneche and Ramos-Flores (2013), as well as Plann (2002), Tilley-Lubbs (2004), and Tilley-Lubbs et al. (2005), call on the $5 \mathrm{C}$ 's as emblematic of the effectiveness of service-learning in the Spanish curriculum, all wonder what heritage learners could gain in linguistic proficiency, thus calling into question either the presence of HLs or the service-learning model. Tilley-Lubbs (2004) alludes to the potential socioeconomic diversity of university students, which we attempt to do in our analysis of students' outcomes. Barreneche and Ramos-Flores conclude that students from diverse ethnolinguistic backgrounds may see no need to opt for CBL opportunities, given their lifelong exposure to economic and social injustice, and the service they already do in unrecognized forms within their communities (p. 221). They suggest that the 2007 MLA Ad Hoc Committee on Foreign Languages report advocating for translingual and transcultural orientations towards language learning ought to supersede the $5 \mathrm{C}$ 's, a recommendation that we embrace.

Some scholars have focused more directly on the HL presence in CBL. Beaudrie, Ducar, and Relaño-Pastor (2009) found that HLs wanted to make community connections a central part of their heritage language instruction in Spanish. Speaking and hearing Spanish through their participation in CBL courses allows HLs to explore linguistic and cultural diversity among Latino/a populations and make comparisons between different Latino/a populations and between Latino/a and non-Latino/a populations. Thompson's (2012) survey of 125 advanced HLs and L2 Spanish students in service-learning courses found that HLs had high levels of agreement with the statement that they had "interacted with people from different social, economic, or ethnic backgrounds" through their service experience (emphasis added, p. 91), suggesting that the "border crossing" model of many CBL programs has significance for HL learners as well as L2 Spanish learners.

Green (2003) calls for greater attention to students' and faculties' diverse socioeconomic and racial backgrounds. Similarly, Carracelas-Juncal (2013) emphasizes that service-learning is not a border-crossing experience for all students; educators must recognize students' positionality in their own communities, their cultural backgrounds and experiences with service, and must develop parallel sets of reflection prompts that recognize the heterogeneity of students' backgrounds.

Guillén (2010) reports that the faculty's lingering doubts about the linguistic value of the CBL experience for HLs were overshadowed by HLs' increased self-esteem related to the impact they had made in the community. These students' reflective writings revealed that "the insecurities many bilingual speakers feel regarding their linguistic competence seemed to be neutralized by 
the pride, empathy, and responsibility resulting from their civic engagement" (2010, p. 49). Although linguistic gains in CBL courses are difficult to measure (Butin, 2006), especially for HLs who typically speak and hear more Spanish outside the classroom than their peers who are L2 learners, the affective gains HLs report related to their community experiences indeed promote language gains if they give Latino/a students greater confidence and motivation to study Spanish and speak it in the community. Petrov (2013) reports similar findings in a servicelearning course for HLs where changes in attitude were more salient than linguistic gains, but suggests that enhanced community connections would reinforce motivations and relevance for continued language study. Leeman et al. (2011) describe a project in which university students became language experts in their interactions with younger students. These examples point towards Leeman's (2011) observation that because the "comparisons" standard asks students to contrast their own culture and language with another culture and language, it reinforces that students are both monocultural and monolingual, which simultaneously "reinforces the Otherness of the community" (p. 302). The most inclusive models for CBL and HLs work to complicate the $5 \mathrm{Cs}$, building on the sociocultural model of language acquisition that they promote, while recognizing the need for more localized and critical assessment models in light of the complexities of identities within classroom and community settings.

Moreover, HLs have varying levels of fluency in Spanish, and very well may achieve linguistic gains similar to what L2 learners experience when speaking and hearing Spanish in community settings. The majority of HLs in the United States speak Spanish at home and in other intimate settings (Carreira \& Kagan, 2011). In fact, Thompson (2012) found that HLs experienced language gains through service-learning because they developed more formal registers as a result of speaking Spanish in professional settings. Through their participation in CBL, HLs not only expand the domains where they speak Spanish, but also reclaim a voice for themselves and community members (Martínez \& Schwartz, 2012). Lear (2013) argues that offering communityservice-learning in Spanish may attract more students to language classes because of "the appeal of real-world, professional training, helping them develop stronger language skills" (p. 67). Gaining greater confidence to speak Spanish in public, semi-professional settings is equally, if not more important for HLs, whose language practices are frequently regulated and stigmatized in both academic and community settings (Zentella, 2005; Leeman et al., 2011; Ducar, 2012; Martínez \& Schwartz, 2012; Potowski, 2012; among others).

Thus notions of CBL and language learning as border-crossing, transformative, and oriented towards linguistic proficiency are challenged by the presence of HL participants. Urciuoli (2013) suggests that monolingual students' lack of language proficiency is seen as a positive kind of deficit around which the act of overcoming communication challenges is a central part of their experience. Meanwhile, marginalization or resistance to the inclusion of HLs in CBL courses is systematic of the policing HLs often confront in Spanish classes, in which their nonstandard language is often denigrated and seen as "broken" (Urciuoli, 2008). To further our point, these models of language learning, and the standard language ideologies that shore them up, would seem ridiculous in an English monolingual CBL setting. The experience would never be seen as less valuable because students continue to speak in their (assumed) native language as they go 
from classroom to community. Unconsidered English monolingualism, of course, makes for its own set of ideologies; indeed, no pedagogy ever asked middle-class Standard American English (SAE) speaking students to try to adapt the marked variety of the community they enter (not that it ever should). This comparison highlights the way that gains in proficiency, acquired by the privileged English monolingual student, can become instrumentalized, even fetishized rationales for CBL in Spanish that exclude HLs and perpetuate a white, monolingualist model of educational achievement. Thus our study seeks to transcend ordinary measures of linguistic proficiency, in turn suggesting that the $5 \mathrm{Cs}$ can be improved to reflect more inclusive theories of language learning.

\section{The Translingual Approach}

Besides building on research in community-based learning, this study is oriented around the "translingual approach" (Horner, Lu, Royster, \& Trimbur, 2011). First emerging in the sociolinguistic study of contemporary globalized networks (Canagarajah, 1999; Pennycook, 2008, 2010; Blommaert, 2010), the translingual approach takes note of the numerous, flexible ways that people cross language boundaries (for example, in code switching) and transcend linguistic categories (for example, in embodied communication, or in digital writing modes such as emojis). Scholars have observed how these forms of communication are afforded by the geographical contact zones that emerge in global migration, as well as by effortless speed and flexibility of digital communication networks. More recently, the translingual approach has been taken up as a generative model for pedagogy among scholars of writing and rhetoric (Young \& Martinez, 2011; Jordan, 2012; Canagarajah, 2013; Canagarajah, 2013) and by sociolinguistic researchers oriented towards bilingual education (Otheguy, García, \& Reed,, 2015). Drawing on sociocultural frameworks, the translingual approach sees meaning as constructed collectively within and across communities, rather than residing in individual speakers, discourses, or codes. As $\mathrm{Lu}$ and Horner (2013) put it, "meaning is necessarily and always the product of translation across differences, even in ostensibly monolingual settings...[I]ndividual language practices are understood as negotiations that have the effect of forming and transforming their contexts, the identities of the participants, and their relations with each other, others, and the world" (p. 2728). In other words, a translingual approach shifts the focus from what people can do with individual languages to how people actively create meaning together. In a collaborative learning setting like the adult ESOL classes which we describe below, a translingual consciousness allows us to worry less about community students acquiring English and university students acquiring tutoring skills (or Spanish), and instead encourage active, collaborative communication in which all members are able to draw on their full range of communicative resources. In the methodologies discussion below, we discuss how we have applied this approach in the development of our assessment rubric, particularly the categories "dialogic communication" and "problem solving."

\section{RESEARCH SETTING}

This project stems from a multi-year collaboration between Drew University and the Morristown Neighborhood House ${ }^{4}$ in northern New Jersey. Neighborhood House, otherwise known as the Nabe, is a community center that has served Morristown for decades as a settlement house, first 
with Italian immigrants at the beginning of the twentieth century, then African Americans who arrived with the Great Migration, and more recently Latin American immigrants, primarily from Guatemala, Honduras, and Colombia. This collaboration began in the fall of 2010 when Drew students in Elise DuBord's Spanish class worked as conversation partners in a new ESOL program and continued with Elizabeth Kimball's English course in the spring of 2011.

In the spring of 2013, we taught our CBL classes in the same semester; the topic of the Spanish class was Latino/a Immigration and the English class on Language and Literacy. This was an intermediary kind of learning community (Trujillo, 2009) where the students were enrolled in two different academic courses, but collaborated in some classroom activities and through the community project. As they had in previous semesters, Drew students worked with individuals and small groups in the ESOL classes at the beginning and intermediate levels once a week over the course of the semester for 12 weeks. Because our courses on campus shared the same time slot, we were able to develop the collaboration in new ways, which led to the production of a book of bilingual oral histories that university students conducted together with community students. This opportunity to collaborate, not only in the community but across academic departments and disciplines, allowed us to design cross-language learning activities, such as the oral history project described below, and also allowed us to research student learning comparatively across language backgrounds.

The community students in the evening ESOL classes represented a different kind of ethnolinguistic diversity than the university students. While all were Latin American immigrants, participants come from many different countries of origin, speak numerous Spanish varieties-a small number also speak indigenous languages - and they had been in the U.S. for varying lengths of time. Moreover, the adult students came from a range of class and educational backgrounds. Some may have had little formal education in their home countries; others had university degrees. A mix of men and women of all ages attended the class, some bringing their children. The teachers at the Nabe also came from a range of backgrounds, including native and non-native English-speakers. These volunteer teachers, while nominally older or more prepared to teach than the university students, did not share common preparation or approaches. The ESOL class was divided into three levels of English proficiency, in three separate rooms; because the mix of volunteer teachers, university student volunteers, and community students was different each week, many classroom decisions were made ad hoc. The university students were meant to serve as tutors and conversation partners in the class. It is the emergent activities and conversations, regardless of one's role in the room or level of language proficiency, that gave the classrooms their energy.

\section{Oral History Project}

The culminating collaborative work of the learners - both community and university - was an oral history project. At the end of the semester, pairs of Drew students (in most cases a student from the English class and another from the Spanish class) interviewed one community ESOL student on assigned topics related to work, childhood, family, and cultural adaptation. The university students received training on conducting oral history interviews and worked in groups 
to develop interview questions, which we then compiled and edited. As part of their training, we prepared Drew students to conduct interviews in English or Spanish, depending on the interviewee's preference. In most cases, ESOL students preferred to be interviewed in Spanish and Spanish-speaking Drew students acted as lead interviewers and translators for their peers with lesser Spanish skills. Exceptions to this pattern were found with advanced ESOL students who were interviewed in English. While the study included university students with a broad range of language backgrounds, a pattern emerged where Spanish HLs, Portuguese and Italian HLs learning Spanish as an L3- and advanced L2 Spanish students, enacted identities as "language experts" (Leeman, Rabin, \& Román-Mendoza, 2011) when they facilitated communication by acting as interpreters and negotiating meaning between Spanish-speaking interviewees and university students who spoke little Spanish in the oral history project. This is potentially empowering for these advanced students of Spanish, who are often reluctant to identify themselves as "bilinguals" or "Spanish speakers."

Each Drew student then wrote a narrative account based on the interviews in the language of the class in which they were enrolled (e.g., students in the English course wrote their narratives in English). These stories were revised, edited, and compiled into a booklet (Kimball \& DuBord, 2013), which was distributed to all participants at the ESOL graduation ceremony at the end of the semester.

Students wrote a great deal about their learning in reflective modes as is common in CBL practice, and we drew on practices common to the field of writing assessment-which has a robust tradition of assessing disparate, complexly layered texts while still maintaining validity (CCCC Committee on Assessment, 1995; Haswell, 2001) - to assess their writing. Students wrote three formal reflection essays ${ }^{\frac{5}{2}}$ and a portfolio essay with the same prompts in both classes, although they wrote their essays in either Spanish or English depending on the language of the class. When the semester was over, we designed a rubric for assessing student writing, which we discuss further in the Methodologies section.

\section{Methodology \\ Goals of the Study}

The study methodology grew out of our own curiosity about what students were really learning in the community collaboration project. We recognized that existing forms of assessment may be disparate from the collaborative ideals that we had in mind when embarking on the project. The object of the study, then, was first to design an inclusive, translingually-informed rubric for assessing student learning, and then to use that rubric to assess self-reported student learning. We soon realized that we had an explicit goal of assessing the learning of heritage language users in comparison to the varied language backgrounds of other students, whether English monolingual or bilingual non-native speakers.

\section{Participants}

While there were numerous stakeholders in the project, this research study examined the learning of the undergraduate university students. The university students in the two courses ranged from 
English monolinguals, L2 learners of Spanish of all levels, heritage and native speakers of Spanish, and students who spoke other languages including Chinese, Italian, Russian, and Portuguese, natively or as an L2. While there was no Spanish language requirement for the students in the English course, the Spanish course was an advanced elective in the Spanish curriculum and students in this class spoke Spanish to varying degrees. In addition, because of the general education requirements at our university, every student had likely already completed the study of a second language through an introductory college level.

Seven of the 13 students in the Spanish class who chose to participate in the study ${ }^{6}$ were Spanish HLs, ${ }^{7}$ in addition, one Portuguese HL and one Italian $\mathrm{HL}^{8}$ in the class were studying Spanish as an L3. Four students in this class were studying Spanish as an L2. With the exception of one Spanish HL, all students were Spanish majors or minors. In the English course, 12 of 14 students were native English monolinguals, ${ }^{2}$ while two students had grown up in Spanish-speaking environments, one of whom was studying Spanish in college. In addition, four students in the English class were pursuing advanced study of Italian, Russian, or Chinese.

\section{Table 1.}

Language Background of University Students in CBL Classes

\begin{tabular}{|l|c|c|c|}
\hline & $\begin{array}{c}\text { Spanish class: } \\
\text { Latino/a } \\
\text { Immigration }\end{array}$ & $\begin{array}{c}\text { English class: } \\
\text { Language and } \\
\text { Literacy }\end{array}$ & Total \\
\hline $\begin{array}{l}\text { Heritage Speakers } \\
\text { of Spanish }\end{array}$ & 7 & 2 & 2 \\
\hline $\begin{array}{l}\text { Heritage Speakers } \\
\text { of Italian or } \\
\text { Portuguese }\end{array}$ & 2 & 0 & 16 \\
\hline $\begin{array}{l}\text { Native English } \\
\text { Monolinguals }\end{array}$ & 4 & 12 & 16 \\
\hline $\begin{array}{l}\text { Major/minor in a } \\
\text { language other than } \\
\text { English }\end{array}$ & 12 & 4 & 27 \\
\hline Class totals & 13 & 14 & \\
\hline
\end{tabular}

\section{Previous Service Experience of University Students}

At the beginning of the semester, students were asked to write about their ethnolinguistic backgrounds, previous experiences with service-learning or community service, and if service 
had had a significant impact on their lives. Based on their self-reported descriptions of previous service, we divided students into groups according to high levels of previous service, low levels of previous service, and no previous service experience. Two students in the English class were also Civic Scholars at Drew, participating in an intensive four-year scholarship program grounded in community engagement whose admission criteria are based primarily on high school service experience. The Civic Scholars also had high levels of service experience, but for the purposes of the analysis that will follow in Section V, they are in a separate category from other students with high levels of previous experience. Students with more service experience, especially those who were part of the Civic Scholar program, tended be from white, monolingual English-speaking families, while students with less service experience tended to be people of color and/or had grown up in multilingual settings. $\frac{10}{}$

Table 2.

Ethnolinguistic/racial Background and Levels of Previous Service

\begin{tabular}{|l|c|c|c|c|}
\hline & $\begin{array}{c}\text { HLs } \\
\text { (Spanish, } \\
\text { Portuguese, } \\
\text { Italian) }\end{array}$ & $\begin{array}{c}\text { People of Color } \\
\text { (not HLs) }\end{array}$ & $\begin{array}{c}\text { Whites } \\
\text { (not HLs) }\end{array}$ & Total \\
\hline $\begin{array}{l}\text { High Service/ } \\
\text { Civic Scholars }\end{array}$ & 0 & 0 & 2 & 10 \\
\hline $\begin{array}{l}\text { High Service / } \\
\text { Not Civic } \\
\text { Scholars }\end{array}$ & 4 & 0 & 4 & 7 \\
\hline Low Service & 2 & 1 & 1 & 8 \\
\hline No Service & 5 & 3 & 11 & 25 \\
\hline Totals & 11 & 3 & 4 & 7 \\
\hline
\end{tabular}

\section{Research Instrument}

The Collaborative Community Engagement Rubric is used to code student reflective writing and measures where individuals fall on a scale of development. We adopted the developmental scale promoted by American Association of Colleges and Universities' (AAC\&U) through their VALUE rubrics (Valid Assessment of Learning in Undergraduate Education), moving from a benchmark entry point at which we believe students arrive in college (a score of 1), to two benchmark stages of progression (scoring 2 or 3 ), to a capstone level where we wish students to be at graduation (scoring a 4). 
Our rubric can be understood as assessing critical engagement because of the categories for assessment that we derived from our experience with the project, and the translingual perspective that we took towards it. These perspectives are inherently collaborative and social. We started with the VALUE rubrics, drawing from the preexisting Intercultural Knowledge and Competence and the Civic Engagement rubrics, and then revised them considerably according to our local needs and critical perspectives. At the same time, we recognize that the practical framework for the assessment of student learning overall examines individual students' growth, and so in adopting the AAC\&U VALUE rubrics' developmental scale to assess student learning in those categories, we acknowledge the necessary tension between practical, conservative needs to document student progress, and idealistic, radical needs to rethink the ways that learning happens and that communities may be transformed.

The translingual approach is particularly salient in cross-language settings of CBL like ours, because there is no one level of proficiency or shared history of literacy practices between any two participants, whether college students or community students (see Kimball, 2015). Indeed, the students in the English class at Drew University in the current study could not have been expected to make gains in the $5 \mathrm{Cs}$; their course was housed in the English Department, a discipline that lies outside ACTFL standards (even though it is, ultimately, the study of language just as much as Spanish is). Although Spanish acquisition was not an objective for this course, English students had similar gains in the areas of cultures, communities, connections, comparisons, and, it can be argued, in translingual communication. We argue that CBL courses are equally valuable for HLs, L2 learners, and monolingual English speakers when they engender greater flexibility in intercultural communication, translingual language practices, cultural competency, and language learning.

The rubric charts development in the five categories outlined below. We describe the categories of Dialogic Communication and Problem Solving at length here as related to our subsequent discussion of student outcomes in these categories. This is followed by a brief description of the categories of Application and Analysis of Academic Knowledge, Confianza (Relationship Building), and Critical Self-Awareness (see the entire rubric in Appendix A) and scored examples from students' reflective writing.

\section{Dialogic Communication (DC)}

The category of Dialogic Communication measures outcomes related to language practices, which we define as the ability to use language creatively to effectively communicate across perceived language boundaries. In this category, we sought to assess the students' approaches to communicating, both in using language flexibly and in responding to the broad rhetorical and affective aspects of conversation with others. As discussed above, this "translingual approach" (Horner et al., 2011; Geisler et al., 2007) is achievable by any student, because it is not a measure of language proficiency; in other words, a fully bilingual English and Spanish speaker could be a poor dialogic communicator, while an English monolingual who embraces dialogic communication could thrive in this cross-language setting. Dialogic communication also indicates the habit of metacognitively reflecting on communication events and one's use of 
language. For example, dialogic communicators exhibit what Firth (1996) calls the "let it pass principle," in which a speaker may not initially grasp the entire meaning of a message, but keeps the conversation moving forward by working towards building a shared meaning with her conversation partner. For example, in Kimball's previous iteration of the course in 2011 a student reported an exchange that not only reflected on language, but developed a bond of humor and good will. While working with an English learner, the university student wanted to know how to say "good job" in Spanish in response to the woman's efforts. The woman's school-age daughter was with her, and so the tutor asked the daughter, who was proficient in English, "what does your mother say to you when you do a good job?" The daughter told her, which the tutor then repeated to the mother: "iMija!" (My daughter!). In this collaborative multilingual environment, the mother instantly understood what had happened and laughed; the tutor showed her own willingness to try out language with the risk of being wrong, and the three participants could all laugh about their topsy-turvy roles. At heart, communicating dialogically responds to people, not to messages, grammars, or levels of proficiency.

Dialogic communication also anticipates the presence of language ideologies- and the ways that communicators react to them. Acting on rigid language ideologies-for example, thinking that only a Standard version of English or Spanish would be acceptable or desirable, or that learning and communication could only take place in one language or the other - can unintentionally hold up communication flow, cause friction with other learners, and block language acquisition. Our goals for our university students included a consciousness of language attitudes that may sound well-intentioned, such as "you need good grammar to get by in America," but that can impede relationship building, prevent problem solving, and impinge on critical self-awareness. In other words, dialogic communication is in many ways a priori to the other categories in our rubric: solving problems, applying and analyzing academic knowledge, building relationships, and becoming critically self-aware. Without the practice of dialogic communication, students are unlikely to be able to meet the other goals either.

\section{Problem Solving (PS)}

This category resists a student-centered mode of problem solving that Urciuoli (2013) has critiqued as coming from a place of neoliberal agency whereby students decide which are the problems worth solving and students' transformation resulting from "doing good" is at the heart of the experience. In the present project, students' task was to work within pre-existing institutional structures with staff, volunteers, and conversation partners at the Nabe and with Drew classmates, and to approach problem solving as a collaborative endeavor. The coupling of the oral history project and ESOL tutoring sought to explicitly create spaces for collaboration with community partners and students across academic disciplines. We wanted students to learn to approach situations in flexible and collaborative ways.

When writing about problem solving in their reflective essays, students frequently focused on language practices that promoted translingual communication with their ESOL conversation partners and relationship-building that enhanced successful communication and learning. When describing their accomplishments as ESOL tutors, students also discussed the techniques their 
conversation partners used to promote communication. Thus problem solving was inherently a mutual endeavor.

\section{Application and Analysis of Academic Knowledge (AAA)}

Students should be able to explain the concepts and information they encounter in the university classroom, and apply, analyze, and evaluate it in light of community experiences. We wanted students to have an integrated experience, coming to understand that the academic setting is just as real as the real-world setting, and that they influence one another in profound ways.

\section{Confianza (Relationship Building) (RB)}

Students should understand the community learners as people with whom they can create (appropriate) human relationships, rather than as clients who can be served. We chose the word confianza for its particular resonance in Spanish, with its connotations of trust, mutual respect, and the notion of being "in confidence" with one another.

\section{Critical Self-Awareness (CSA)}

Students should come to recognize their own situatedness in a network of race, class, ethnicity, language, education, gender, and other factors. We wanted students to understand that they are a part of a set of discourses and cultures that shape the world, and that shut out some and include others.

After compiling the student writing at the end of the semester, research assistants read and coded the students' final reflection essays and portfolio essays according to the rubric. Two research assistants coded student writing (one in English and one in Spanish) for rubric categories in each essay and scored the categories identified using the Collaborative Community Engagement rubric. A third research assistant independently scored each essay; discrepancies in the scoring were resolved by the researchers by averaging in an additional score. The discussion that follows presents examples of student writing and their scores ("PS" refers to the "Problem Solving" category and "DC" to "Dialogic Communication"; the names are pseudonyms). Admittedly, we are measuring our students' self-reported outcomes in this area, rather than observing communicative practices or exploring the outcomes of this collaboration for our community partners.

\section{Student Writing, Dialogic Communication ${ }^{11}$}

\section{Example 1}

Tuve que aprender a explicar la relación o diferencia entre los idiomas, español e inglés, para que pudiera enseñar. Si un estudiante no entendió algo, tuve que usar palabras diferentes para que entonces pudiera entender. Tuve que encontrar la manera de comunicar a cada estudiante por eso pudiera aprender. Tuve que ver la cantidad de inglés que podría usar con los estudiantes en comparación con la cantidad de español que tuve que hablar para 
comunicarme. Aunque comprendo que la inmersión total es la manera más rápida de aprender un idioma, me siento que no podía caminar por allí y hablar sólo inglés a ellos, quería que la experiencia sea agradable. [...]. Necesité romper la barrera con ellos y comunicarse en el mismo idioma es la manera de hacerlo. Ahora hablo inglés con los estudiantes y menos español y los estudiantes hacen lo mismo. (DC 4, PS 4, Carmela, HL Italian, Spanish L3) [I had to learn to explain the relation or difference between the languages, Spanish and English, in order to teach. If a student did not understand something, I had to use different words so that he/she could understand. I had to find the way to communicate with every student so that he/she could learn. I had to decide the quantity of English that I could use with the students in comparison with the quantity of Spanish I had to speak to communicate. Although I understand that total immersion is the fastest way to learn a language, I feel that I could not walk down that path and speak only English with them, I wanted the experience to be pleasant. [...]. I needed to break the barrier with them and communicating in the same language is the way to do it. Now I speak English with the students and less Spanish and the students do the same. ]

Carmela was, without a doubt, a language person. In addition to growing up in a bilingual Italian/English environment and studying Italian formally, she had taken on the serious study of Spanish as an L3, and had also dabbled in the informal study of three other languages. Her own language experience and disposition to language learning had primed her for dialogic communication. Not only did she have the necessary language skills in Spanish to communicate with her conversation partners in their L1, she was also adept at adjusting the ways she used language practices with different interlocutors over time. She was willing to dispense with received language pedagogy ("immersion is best") in favor of an approach that would engender more positive feelings as well as language acquisition. In this way we see the overlap between the categories of Problem Solving and Dialogic Communication: flexible and creative language practices promote effective learning and communication.

\section{Example 2}

The most obvious problem stemming from language differences is trouble with communication. Nevertheless, with a classroom full of bilingual and multilingual resources, rarely was a language difference an absolute barrier for communication. Ironically enough these same places of difference that spawned the communication problems are also the points of opportunity. The same language differences that hindered my communication with the student were often the same differences that were needed to teach them English. I've learned in class and then in practice that approaching such differences with a translingual disposition, an approach aimed at exploring the areas in-between languages rather than decisively one or the other, transforms points of 
divergence into points of convergence where we can both learn together about each other's languages, identities, and cultures. (DC 4, William, English monolingual)

While William was least exposed to an L2 as compared with other students - he had struggled with college-level language study and had finally been exempted due to his dyslexia - he grasps the way in which language and communication exist only as something among people, in a certain context, rather than as residing in an individual, as Vygotsky and Cole (1981) believe. It was actually William's own lack of proficiency that created the opportunity to work towards understanding.

\section{Student Writing, Problem Solving}

Example 3

Cuando comencé a ayudar en Neighborhood House, yo aprendí que una de las cosas más importantes fue tomando el tiempo de conocer los estudiantes de ESOL. Construyendo una relación con los estudiantes, fuimos capaces de ganar confianza y el respecto de uno a otro. Formando la confianza y el respecto, proporcionó una atmósfera de comodidad, para el estudiante de ESOL y yo mismo, para que todos tenían el sentido que pudieron hacer preguntas libremente y abiertamente sin vergüenza. (PS 3.5, RB 4, Maribel, Spanish HL)

[When I started helping at Neighborhood House, I learned that one of the most important things was taking the time to get to know the ESOL students. Building a relationship with the students, we were able to gain the trust and respect of one another. Forming trust and respect, provided an atmosphere of comfort for the ESOL student and for myself, so that everyone had the sense that they could freely and openly ask questions without embarrassment.]

Maribel, a heritage speaker of Spanish, was taking college-level Spanish for the first time in this course. Her writing connects the categories of Problem Solving with Relationship Building, stressing the importance of trust and respect as prerequisites to learning in this setting. Maribel was not entering a foreign culture through her work as a tutor or communicating in a foreign language, but rather she embraced the need for personal connections and interpersonal rapport.

\section{Example 4}

Surprisingly enough I am not the only one who is the teacher, at the Neighborhood House. I have learned many new verbs and words from my ESL students, and they are very quick to tell me the correct way to say it. One day, a beginner student and I were writing out sentences in English and if she did not understand the words I would translate it for her. Well on that day I learned that a common word like milk in Spanish was actually a feminine word. I was 
blown away by that idea when she read over the sentence and spotted my mistake. Another time I wanted to tell another student was working with to erase something, but I had no idea what the word to erase was in Spanish. So, I asked the student who I interviewed for my Oral History Project, "What iserasing something on the page-verb in Spanish?" He understood what I was asking and told me, and even told me what an eraser was in Spanish, and then I told him what the action and noun are in English. After that we maintained a game of 20 questions where he asked me how to say certain things in English and I asked him how to pronounce it in Spanish. It was quite refreshing how easily we could communicate with hand gestures and pictures, even with our slight language barrier. (DC 3, PS 3, Karine, Spanish HL, and identifies as African American)

Karine was a HL of Spanish enrolled in the English course on Language and Literacy whose was concurrently studying Spanish at a lower level. Although she had limited exposure to Spanish growing up, she identified it as being part of her cultural heritage and something she had worked to acquire in school and made an effort to seek out Spanish-speaking environments. In Example 4 above, it is apparent that communicating in Spanish is sometimes a struggle, but one that she creatively and mutually negotiates with her conversation partner. Like Carmela in Example 1, Karine links Problem Solving and Dialogic Communication. Although her language proficiency in Spanish was lower than Carmela's, she is able to overcome perceived language gaps through reciprocal learning practices.

\section{RESULTS AND DisCUSSION}

This section examines assessment results in two categories, Dialogic Communication (DC) and Problem Solving (PS), which revealed the most distinct differences among types of students. In the following, we first examine the correlation between students' language backgrounds and their outcomes in DC and PS. This is followed by students' outcomes in these categories according to their previous experiences doing community service prior to their enrollment in these CBL courses.

\section{Language Background}

In the category of Dialogic Communication shown in Figure 1, heritage speakers of Spanish had average scores of 2.9, and heritage speakers of Italian and Portuguese had average scores of 3.3. Both groups were much higher than native English monolinguals who had a raw score of 2.0 and an adjusted average of 2.1. $\frac{12}{\text { It }}$ is perhaps unsurprising that students who had grown up in multilingual environments and/or had chosen to study a third language would be particularly competent in using language flexibly and creatively to communicate in community settings. 


\section{Figure 1.}

\section{Language Background and Dialogic Communication (DC)}

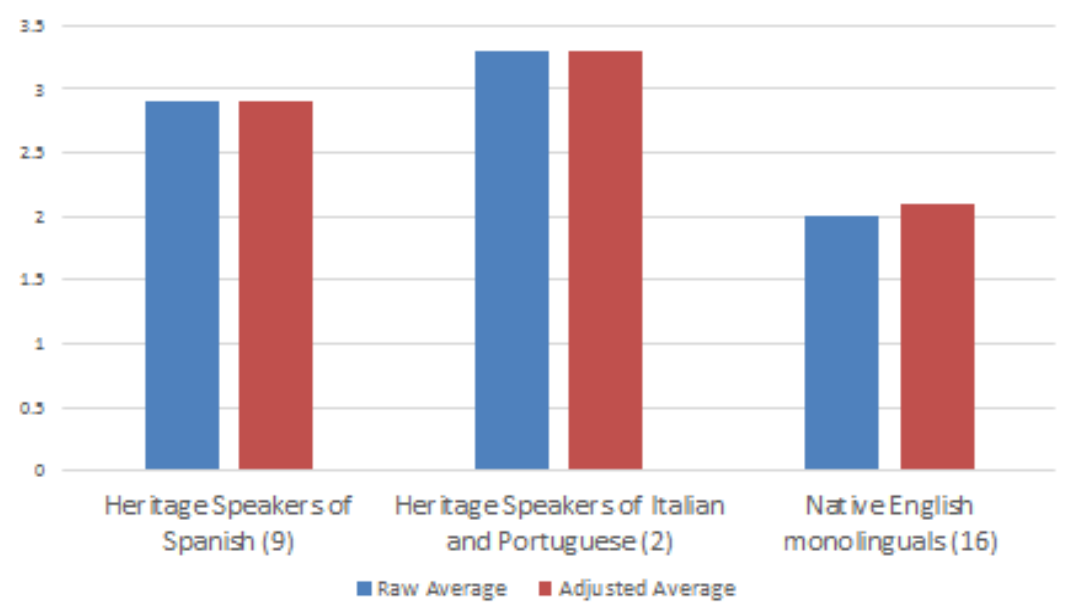

Heritage speakers of Spanish also excelled in the category of Problem Solving (see Figure 2). They had higher scores (2.6) than other heritage speakers (1.9) and native English monolinguals (1.5 raw/1.8 adjusted). These scores suggest that heritage speakers possess a greater familiarity with the issues that may arise in community settings and a greater capacity to collaboratively respond to community issues at the Nabe or in the oral history project.

Figure 2.

\section{Language Background and Problem Solving (PS)}

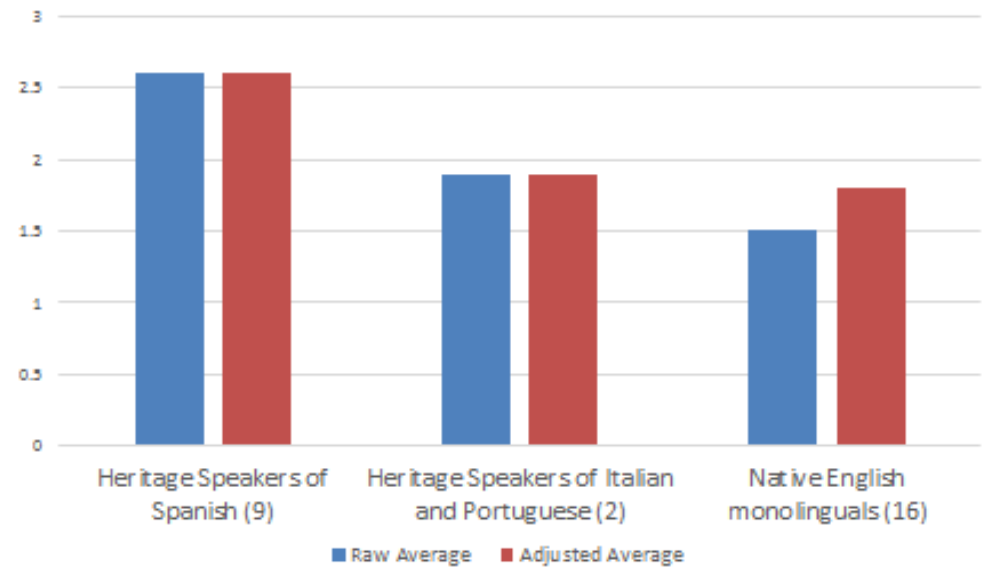


In one final note about heritage speakers, three heritage speakers of Spanish were missing scoring in the area of Application and Analysis of Academic Knowledge (AAA); in other words, nothing in their writing seemed to speak directly to the category. This absence resulted in almost a 1-point difference in the raw (1.9) and adjusted averages (2.8). Although the adjusted averages in AAA were higher among heritage speakers than non-heritage speakers, these results suggest that while some heritage speakers successfully made explicit connections between academic work and community work, others did not name this aspect of community work as being central to their experience. Two of these students were enrolled in the English course, where Spanish, of course, was not the medium of instruction and therefore did not frame the experience in the same way that it did in the Spanish course, despite the importance of the Spanish language as a course topic as related to community literacy. These students had a harder time making the connection between their experiences at the Nabe and traditional academic course content, which supports our argument for the importance of integration of CBL in the Spanish curriculum for HLs. We found this discrepancy to be significant because some of these HLs who did not "code" as great students - they were not exceedingly conscientious about assignments, careful readers, or writers who responded fully to prompts designed by teachers - thrived in the community setting. If CBL courses, particularly in Spanish courses with HLs, push students to more explicitly link their language skills and community knowledge with academic content, the experience is more productive for their academic development.

These results also led us to think about the impact of formal language study and its impact on outcomes among students. This collaboration was unique in that it involved college students with diverse language backgrounds; we had students who were language majors and minors in Spanish, Italian, Chinese, and Russian. At the same time, these students worked alongside students who had not taken language courses beyond the minimum general education requirement. This context gives us an opportunity to compare different kinds of language heritage and formal study. In other words, does intensive college language study have an impact on student outcomes among second language learners? In the area of Dialogic Communication (see Figure 3), HLs of any language - 9 of the 11 were pursuing a language major or minorhad the highest overall outcomes (2.9). Among students in the English course, Native English monolinguals with language majors and minors (4 in Spanish and one each in Chinese, Italian, and Russian) had better outcomes (2.2 raw/2.6 adjusted) than L2 students without language majors and minors (1.8 raw/2.0 adjusted). 


\section{Figure 3.}

\section{Language Study and Dialogic Communication (DC)}

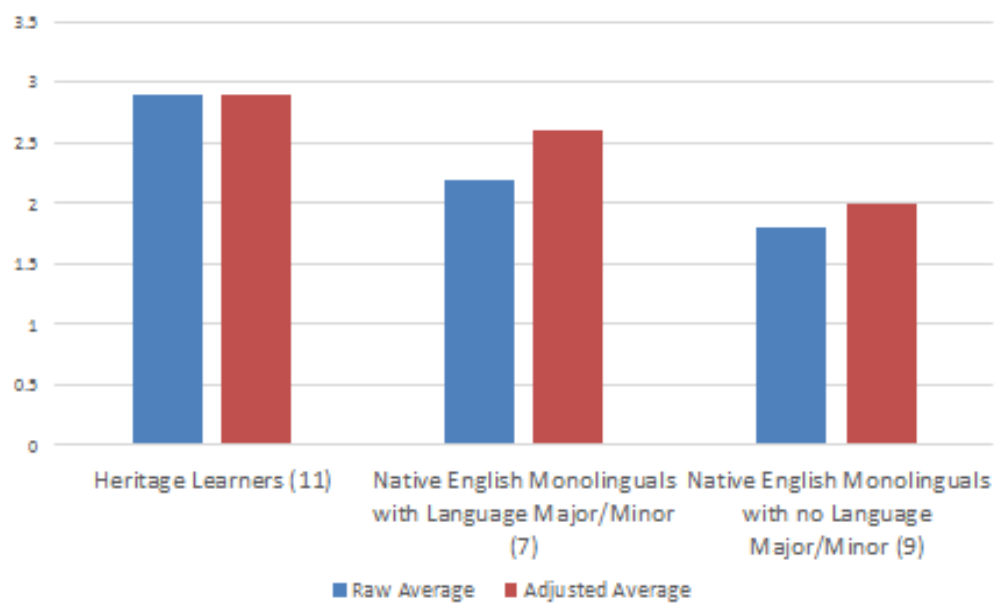

This difference was despite more explicit academic content coverage on translingual language practices in the English course where students were not expected to have language proficiency in other languages. Although native English monolinguals with language majors or minors in a variety of languages have results that are lower than the overall scores for all HLs in the area of DC, they demonstrate a positive correlation between intentional and dedicated language studyregardless of the language - and communication skills as compared to their monolingual peers who have not pursued advanced language study.

Thus it seems as though being an HL, especially among those who take on college-level language study, is the gold standard for reaching higher levels of learning. As teachers and project designers, we might interpret this information to mean that we should facilitate learning experiences that give all students the chance to learn in ways the heritage speakers learninformally, in intimate and casual settings, with a high opportunity to build relationships with speakers of the language who are not teachers or other public authority figures. Urciuoli (2013) questions if academic programs give students the necessary skills to carry out civic engagement. Our results suggest that serious language study may indeed prepare students for these kinds of experiences.

\section{Previous Service Experience}

We identified a somewhat surprising contrast in outcomes in students when they were grouped by their reported levels of previous community service experience. As described in section IV, we divided students into groups according to their self-reported levels of previous service experience (see Figure 4). In the category of Problem Solving (PS), students who had no previous service experience had the highest outcomes (2.3 raw/2.6 adjusted), low service 
experiences had slightly lower outcomes (1.9 raw/2.2 adjusted), and high levels of service (1.6 raw/1.8 adjusted) had the lowest outcomes. The Civic Scholars had the lowest scores (1.3) as compared to the other groups. Therefore, there was a negative correlation between more previous service experience and higher outcomes in PS.

Figure 4.

\section{Problem Solving and Service Experience}

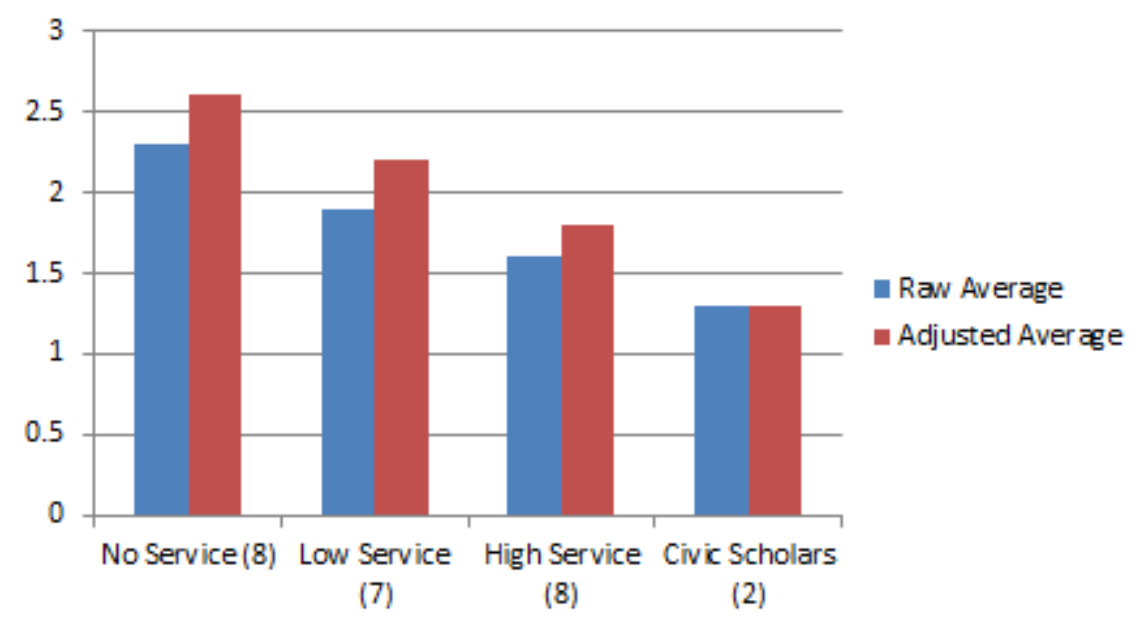

A similar pattern appears with DC (see Figure 5) where students with no service experience scored 2.8, low service experience scored $2.0 \mathrm{raw} / 2.8$ adjusted, high service scored 2.6, and Civic Scholars 1.3. This pattern, given what we would expect of students with a background in community work, seems surprising and puzzling. 


\section{Figure 5.}

\section{Dialogic Communication and Service Experience}

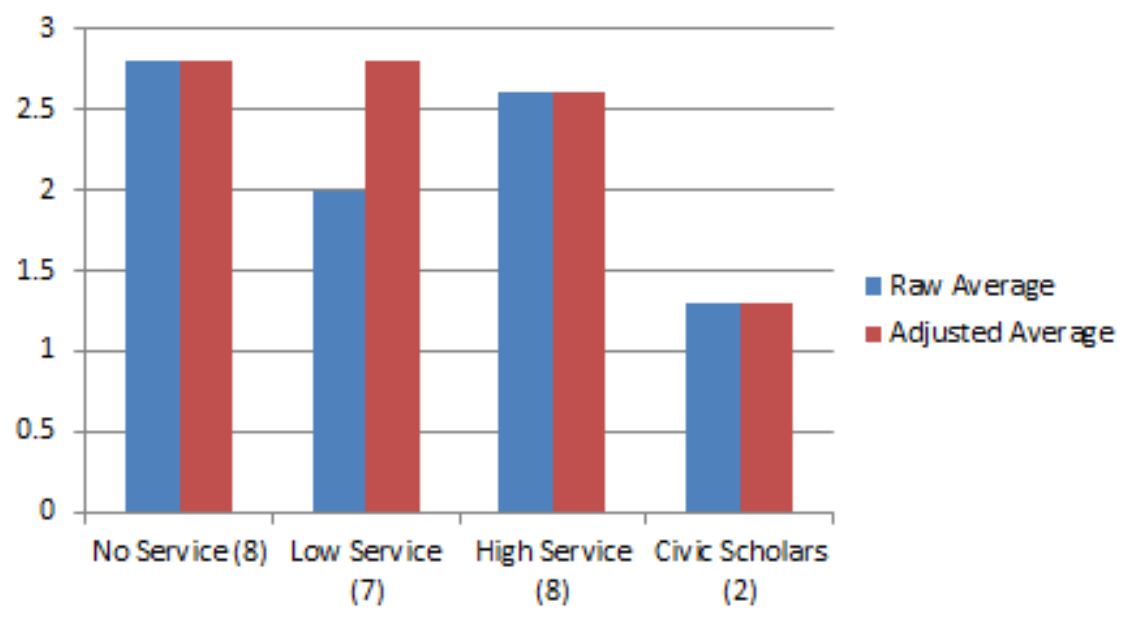

These results raise questions about whether the service learning movement is achieving its desired outcomes. We argue that these numbers say more about the students who typically do more recognizable and rewarded service in the first place: students who fall lower on the diversity scale (see Table 1). A similar pattern emerged in the category of Confianza: the students with higher levels of service earned lower scores in the kind of trust-based relationship building that we believe is important enough to warrant its own category in the rubric. While we may interpret this data to suggest that programs like Civic Scholars may not be meeting the outcomes they promise, we can also interpret it to mean that life itself is a better teacher. If you have spent your whole life moving back and forth between communities and languages, you have spent many more hours working on these skills than a white, middle-class, and probably affluent, monolingual college student has, and certainly more than we can teach in 25 hours of off-campus work in a single semester.

We would suggest that in some ways, the rhetoric of service may create a sense that service is for those who see themselves as privileged, an identity that correlates with English monolingual, monocultural identity. As Green (2003) writes, "Students often seek service-learning classes because they want to 'feel good' about 'helping others," adding that this expectation of feeling good can make it even harder for students to move past comfortable reflections from the vantage point of their own subject position (p. 282). ${ }^{13}$ In sum, previous service experience, with or without critical reflection, was negatively correlated with students' outcomes. We do not doubt the enormous benefit of civic engagement programs to both students and the university in general — we are a part of one, after all — but rather suggest that we become more attentive to the 
discourse around service and how that language may be unintentionally excluding ethnolinguistically diverse students from joining and contributing to these programs.

Based on anecdotal evidence from our students, we also believe that many HLs who reported low or no service may actually be doing similar kinds of activities that students with high levels of service are good at reporting and quantifying. For example, if a student helps a younger sibling with her homework, is he just a good big brother or an "after-school mentor"? If a student from a Spanish-speaking family acts as a language broker for her parents at the doctor, is this student doing any less service than her peers who do community outreach with new immigrants? What might typically be described as service when it happens outside of one's family or community is just as valuable, if not more so, when done in intimate settings where there is a greater imperative to actively engage in the process. Conducting service outside of one's community is regularly lauded, especially among white, middle-class, English speakers, not only because of the good works they do in less-fortunate communities, but because of the border crossing ${ }^{14}$ in which they engage as part of this process. Students from immigrant families, students of color, and first generation college students may not have had the same opportunities to do traditionally quantifiable service. Yet, as was discussed in the literature review of HLs in CBL, these students sometimes confront institutional resistance to their participation in these programs precisely because of the lived experiences that prepare them to be successful in community settings. There is also a lack of acknowledgement that traditionally defined previous service may not be the only measure of interest or aptitude for community engagement.

\section{CONCLUSION}

In the same way that HLs are sometimes advised, particularly by faculty outside language departments, that studying Spanish is a waste of their time because they already speak Spanish, there is less of an imperative for those who grew up in underrepresented communities to participate in CBL. We suggest that just as ethnolinguistic minorities' language skills are often undervalued in comparison with L2 language learners, their previous service experiences, especially when tied to family or their local communities, are undervalued as compared to their White peers who are more likely to have conducted service outside their own communities. We would never tell students who had excelled in biology or theater in high school that they should abandon these fields; on the contrary, we encourage them to take more classes or try out for the theatre production. Shouldn't we afford students the same encouragement and recognition for their language aptitude and community engagement, at whatever level it happens? In other words, despite the liberatory promise of CBL, we have continued to rely on unexamined assumptions of social and linguistic capital that reinscribe roles of the needer and the giver.

These roles mask the double bind of immigrant language as both an inheritance that is an underdog in the linguistic marketplace (Bourdieu, 1991), and as an academic subject with significant status in the marketplace. As Velázquez (2015a) points out, Spanish as a heritage language might have social bonding capital in the home and neighborhood, but little economic and cultural capital to achieve success in the middle-class sense, for example in the form of scholarships, college credits, and belonging in professional discourse communities. The opposite 
is true for L2 learners: Spanish bears cultural capital because it is perceived as having instrumental value, but garners little social capital because the non-heritage speaker generally lacks a palpable connection with Spanish-speaking communities. ${ }^{15}$

While we recognize the paradoxes of the various forms of capital that Spanish invokes, CBL classes allow students to apply their strengths and abilities in community settings, and also give students the opportunity to assess and reflect on professional and interpersonal skills they are developing. They align with the increasing professionalization of Spanish as a discipline (Spanish for the Professions, internships, etc.) and should be a goal for HLs and second language learners alike. More critically, they should be designed in such a way that they bring students to greater consciousness about these competing forms of capital and how individuals negotiate them. Projects that bring university and community members together as learners and shared researchers help to do this; so does classroom material that orients students to language ideologies and the varied ways that individuals encounter these ideologies. Moreover, our research shows that instructors must carefully consider their assessment methods, seeking out underlying assumptions about language proficiency, what counts as a "good student," and how assignment genres may limit or open up learning possibilities for students from diverse ethnolinguistic backgrounds. Such work - taking place at the level of the individual class session or the individual assignment prompt - telescopes into broader cultural notions of what counts as success. If we are to fully integrate heritage learners into the core of our discipline, we must come to terms with what we mean by successful language learning.

\section{ACKNOWLEDGEMENTS}

We are grateful for the continued hard work and good will of the staff of the Morristown Neighborhood House in Morristown, New Jersey, particularly Rosa Chilquillo and Jennifer Huber, in addition to the teachers and students of the evening ESOL classes. We thank Amy Koritz and the Center for Civic Engagement at Drew University for support for this ongoing community partnership. We also thank our research assistants, Nicole Waters and Megan Day at Drew University and Elizabeth Becker at the University of Northern Iowa. Funding for this project was provided by Faculty Research Grants at Drew University and the Graduate College Summer Fellowship and the Department of Languages \& Literatures, both at the University of Northern Iowa.

\section{REFERENCES}

Barreneche, G. I. \& Ramos-Flores, H. (2013). Integrated or isolated experiences? Considering the role of service-learning in the Spanish language curriculum. Hispania, 96(2), 215-228.

Beaudrie, S., Ducar, C. \& Relaño-Pastor, A. (2009). Curricular perspectives in the heritage language context: Assessing culture and identity. Language, Culture, and Curriculum, 22(2), 157-174.

Beebe, R. M., \& De Costa, E. M. (1993). The Santa Clara University Eastside project: Community service and the Spanish classroom. Hispania, 76(4), 884-891. 
Blommaert, J. (2010). The Sociolinguistics of Globalization. Cambridge, UK; New York: Cambridge University Press. Print. Cambridge Approaches to Language Contact.

Bourdieu, P. (1991). Language \& symbolic power. J. B. Thompson (Ed.). Cambridge, MA: Harvard University Press.

Broad, B. (2003). What we really value: Beyond rubrics in teaching and assessing writing. Logan: Utah State UP.

Butin, D. W. (2006). Putting Foucault to work in educational research. Journal of Philosophy of Education, 40(3), 371-380.

Canagarajah, A. Suresh. (1999). Resisting linguistic imperialism in English Teaching. Oxford: Oxford University Press.

Canagarajah, A. Suresh (Ed.). (2013). Literacy as translingual practice: Between communities and classrooms. New York, NY: Routledge.

Canagarajah, A. Suresh. (2013). Translingual practice: Global Englishes and cosmopolitan relations. New York, NY: Routledge.

Carracelas-Juncal, C. (2013). When service-learning is not a "border-crossing" experience: Outcomes of a graduate Spanish online course. Hispania, 96(2), 295-309.

Carreira, M., \& Kagan, O. (2011). The results of the National Heritage Language Survey: Implications for teaching, curriculum design, and professional development. Foreign Language Annals, 44(1), 40-64.

CCCC Committee on Assessment (1995). Writing assessment: A position statement. College Composition and Communication, 46(3), 430-437.

De Leon, N. (2014). Developing intercultural competence by participating in intensive intercultural service-learning. Michigan Journal of Community Service Learning, 21(1), 1730 .

Ducar, C. (2012). SHL learners' attitudes and motivations: Reconciling opposing forces. In S.M. Beaudrie and M. Fairclough (Eds.), Spanish as a heritage language in the United States: The state of the field (pp. 161-178.). Washington, DC: Georgetown University Press.

Eyler, J., Giles Jr., D. E., Stenson, C. M., \& Gray, C. J. (2001). At a glance: What we know about the effects of service learning on college students, faculty, institutions, and communities, 1993-2000 (3rd ed.). Washington, DC: Corporation for National and Community Service.

Firth, A. (1996). The discursive accomplishment of normality: On 'lingua franca' English and conversation analysis. Journal of Pragmatics, 26(2), 237-259.

Gallagher, C. W. (2012). The trouble with outcomes: Pragmatic inquiry and educational aims. College English, 75(1), 42-60.

Geisler, M., Kramsch, C., McGinnis, S., Patrikis, P., Pratt, M. L., Ryding, K. Saussy, H. (2007). Foreign languages and higher education: New structures for a changed world: MLA ad hoc committee on foreign languages. Profession, 234-245.

Green, A.E. (2003). "Difficult stories: Service-learning, race, class, and whiteness." College Composition and Communication, 55(2), 276-301.

Guillén, F. (2010). Including Latino communities in the learning process: Curricular and pedagogical reforms in undergraduate Spanish programs. Journal of Community Engagement and Scholarship, 3(2), 41-53. 
Hale, A. (1999). Service learning and Spanish: A missing link. In J. Hellebrandt \& L. T. Varona (Eds.), Construyendo puentes (Building Bridges): Concepts and models for service-learning in Spanish (pp. 9-31). Washington, DC: American Association for Higher Education.

Haswell, R. H., (2001). Beyond outcomes: Assessment and instruction within a university writing program. Westport, CT: Ablex.

Hellebrandt, J., ,\& Varona, L. T. (Eds.). (1999). Construyendo Puentes = Building Bridges: Concepts and models for service-learning in Spanish (series on Service-Learning in the Disciplines). Washington, DC: American Association for Higher Education .

Hellebrandt, J., Arries, J., \&Varona, L. T. (Eds.). (2003). Juntos: Community partnerships in Spanish and Portuguese (Professional Development Series Handbook v. 5). Boston, MA: Thomson/Heinle. -

Horner, B., Lu, M. Z., Royster, J. J., \& Trimbur, J. (2011). Language difference in writing: Toward a translingual approach. College English, 73(3), 303-321.

Hussey, T. \& Smith, P. (2008). Learning outcomes: A conceptual analysis. Teaching in Higher Education, 13(1), 107-115.

Jordan, J. (2012). Redesigning composition for multilingual realities. Urbana, IL: Conference on College Composition and Communication of the National Council of Teachers of English. -

Kimball, E. (2015). Translingual communities: Teaching and learning where you don't know the language. Community Literacy Journal, 9(2), 68-82.

Kimball, E., \& DuBord, E. (Eds.) (2013). La Travesía: Una colección bilingüe de historias orales / The journey: A bilingual collection of oral histories. Madison, NJ: Drew University. Retrieved from http://media.wix.com/ugd/9baab3_a67060d0fcd74e3ca6e9749f17f06837.pdf

Lear, D. (2013). Service-learning: Bridging the past and the future for university foreign language programs. Michigan Journal of Community Service Learning, 20(1), 65-69.

Leeman, J. (2011). Standards, commodification, and critical service learning in minority language communities. Modern Language Journal, 95(2), 300-303.

Leeman, J., Rabin, L., \& Román-Mendoza, E. (2011). Identity and activism in heritage language education. Modern Language Journal, 95(4), 481-495.

Lu, M., \& Horner, B. (2013). Translingual literacy and matters of agency. In A. S. Canagarajah (Ed.), Literacy as translingual practice: Between communities and classrooms (pp. 26-38). New York, NY: Routledge.

Martínez, G., \& Schwartz, A. (2012). Elevating low language for high stakes. Heritage Language Journal, 9(2), 37-49.

Mitchell, T. D. (2008). Traditional vs. critical service-learning: Engaging the literature to differentiate two models. Michigan Journal of Community Service Learning, 14(2). 50-65.

Molee, L. M., Henry, M. E., Sessa, V. I., \& McKinney-Prupis, E. R. (2010). Assessing learning in service-learning courses through critical reflection. Journal of Experiential Education, $33(3), 239-257$.

Morris, F.A. (2001). Serving the community and learning a foreign language: Evaluating a service-learning programme. Language, Culture, and Curriculum, 14(3), 244-255. 
Mullaney, J. (1999). Service-learning and language-acquisition theory and practice. In J. Hellebrandt \& L.T. Varona (Eds.), Construyendo puentes (Building bridges): Concepts and models for service learning in Spanish (pp. 49-60). Washington, DC: American Association for Higher Education.

Nelson, A. L., \& Scott, J. L. (2008). Applied Spanish in the university curriculum: A successful model for community-based service-learning. Hispania, 91(2), 446-460.

Novak, J. M., Markey, V., \& Allen, M. (2007). Evaluating cognitive outcomes of service learning in higher education: A meta-analysis. Communication Research Reports, 24(2), $149-157$.

Olazagasti-Segovia, E. (2003). Second language acquisition, academic service-learning, and learners' transformation. In J. Hellebrandt, J. Arries, \& L. T. Varona (Eds.), Juntos: Community partnerships in Spanish and Portuguese (pp. 5-16). Boston, MA: Thomson/Heinle.

Otheguy, R, García, O., \& Reid, W. (2015). Clarifying translanguaging and deconstructing named languages: A perspective from linguistics. Applied Linguistics Review, 6(3), 281-307.

Overfield, D.M. (1997). From the margins to the mainstream: Foreign language education and community-based learning. Foreign Language Annals, 30(4), 485-491.

Pedersen, P. J., Meyer, J. M., \& Hargrave, M. (2015). Learn global; Serve local: Student outcomes from a community-based learning pedagogy. Journal of Experiential Education, 38(2), 189-206.

Pellettieri, J. L. (2011). Measuring language-related outcomes of community-based learning in intermediate Spanish courses. Hispania, 94(2), 285-302.

Pennycook, A. (2008). "Translingual English." Australian Review of Applied Linguistics, 31(3), 30.1-30.9.

Pennycook, A. (2010). Language as a local practice New York, NY: Routledge.

Petrov, L. (2013). A pilot study of service-learning in a Spanish heritage speaker course: Community engagement, identity, and language in the Chicago area. Hispania, 96(2), 310327.

Plann, S. J. (2002). Latinos and literacy: An upper-division Spanish course with service learning. Hispania, 85(2), 330-338.

Potowski, K. (2012). Identity and heritage learners: Moving beyond essentializations. In S. M. Beaudrie \& M. Fairclough (Eds.), Spanish as a heritage language in the United States: The State of the Field (pp. 179-199). Washington, DC: Georgetown University Press.

Ter Horst, E. E., \& Pearce, J.M. (2010). Foreign languages and sustainability: Addressing the connections, communities, and comparisons standards in higher education. Foreign Language Annals, 43(3), 365-383.

Thompson, G. (2012). Intersection of Service and Learning: Research and Practice in the Second Language Classroom. Charlotte, NC: Information Age.

Tilley-Lubbs, G. A. (2004). Crossing the border through service-learning: From practice to theory. Hispania, 87(1), 135-136. 
Tilley-Lubbs, G. A. (2007). The intersection of the academy and the community: Researching relationships through community-based education. In A. J. Wurr \& J. Hellebrandt (Eds.), Learning the language of global citizenship: Service-learning in Applied Linguistics (pp. 297-324). Bolton, MA: Anker.

Tilley-Lubbs, G. A., Raschio, R., Jorge, E., \& López, S. (2005). Service learning: Taking language learning into the real world. Hispania, 88(1), 160-167.

Trujillo, J. A. 2009. Con Todos: Using learning communities to promote intellectual and social engagement in the Spanish curriculum. In M. Lacorte \& J. Leeman (Eds.), Español en Estados Unidos y otros contextos de contacto (pp. 369-395). Frankfurt, Germany; Madrid, Spain:: Vervuert/Iberoamericana.

Urciuoli, B. (2008). Whose Spanish? The tension between linguistic correctness and cultural identity. In M. Niño-Murcia \& J. Rothman (Eds.), Bilingualism and identity: Spanish at the crossroads with other languages (pp. 257-277). Amsterdam: Benjamins.

Urciuoli, B. (2013). The promise and practice of service learning and engaged scholarship. Learning and Teaching, 6(2), 1-10.

Velázquez, I. (2015a, March 28). On relevance: Sociolinguistic inquiry and the teaching of U.S. varieties of Spanish. Paper presented at 25th Conference on Spanish in the United States. City College of New York, NY.

Velázquez, I. (2015b) Reported literacy, media consumption and social media use as measures of relevance of Spanish as a heritage language. International Journal of Bilingualism. Prepublished July 23, 2015 as DOI:10.1177/1367006915596377.

Vygotsky, L. S., \& Cole, M. (1981). Mind in society: The development of higher psychological processes. Cambridge, MA: Harvard UP.

Weldon, A., \& Trautmann, G. (2003). Spanish and service-learning: Pedagogy and praxis. Hispania, 86(3), 574-583.

Young, V. A., \& Martinez, A. Y. (Eds.). (2011). Code-meshing as World English: Pedagogy, policy, performance. Urbana, IL: National Council of Teachers of English.

Zapata, G. (2011). The effects of community service learning projects on L2 learners' cultural understanding. Hispania, 94(1), 86-102.

Zentella, A. C. (2003). “José can you see?" Latin@ responses to racist discourse. In D. Sommer (Ed.), Bilingual Aesthetics (pp. 51-66). New York, NY: Palgrave.

Zentella, A. C. (2005). Building on strength: Language and literacy in Latino families and communities. New York, NY; Covina, CA:: Teachers College Press; California Association for Bilingual Education. 


\section{APPENDIX \\ Collaborative Community Engagement Rubric}

In all categories, evidence can be found only in self reporting; therefore, proof of having achieved the trait is indirect. However, because it has been self-reported, we can assume a level of consciousness or metacognitive awareness that would indicate rich learning.

\begin{tabular}{|c|c|c|c|c|}
\hline & \multirow{2}{*}{$\begin{array}{c}\text { Capstone } \\
4 \\
\end{array}$} & \multicolumn{2}{|c|}{ Milestone } & \multirow{2}{*}{$\begin{array}{c}\text { Benchmark } \\
1 \\
\end{array}$} \\
\hline & & 3 & 2 & \\
\hline $\begin{array}{l}\text { Dialogic } \\
\text { communication }\end{array}$ & $\begin{array}{l}\text { Effectively } \\
\text { communicates in } \\
\text { community } \\
\text { context, showing } \\
\text { recognition of } \\
\text { listening, using } \\
\text { language } \\
\text { creatively, and } \\
\text { adapting ideas } \\
\text { and messages } \\
\text { based on and in } \\
\text { response to } \\
\text { others' } \\
\text { perspectives, and } \\
\text { communicative } \\
\text { practices. } \\
\text { Reveals } \\
\text { metalinguistic } \\
\text { understanding of } \\
\text { the flexibility } \\
\text { and creative } \\
\text { possibilities of } \\
\text { translingual } \\
\text { communication, } \\
\text { as well as it } \\
\text { challenges and } \\
\text { theoretical } \\
\text { complexities. }\end{array}$ & $\begin{array}{l}\text { Effectively } \\
\text { communicates in } \\
\text { community context, } \\
\text { showing } \\
\text { recognition of } \\
\text { listening, using } \\
\text { language creatively, } \\
\text { and adapting ideas } \\
\text { and messages based } \\
\text { on others' } \\
\text { perspectives. } \\
\text { Understands the } \\
\text { possibility and } \\
\text { challenges of cross- } \\
\text { lingual/translingual } \\
\text { communication. }\end{array}$ & $\begin{array}{l}\text { Attempts to } \\
\text { communicate } \\
\text { in community } \\
\text { context, } \\
\text { showing } \\
\text { recognition of } \\
\text { listening, } \\
\text { using language } \\
\text { creatively, and } \\
\text { adapting ideas } \\
\text { and messages } \\
\text { based on } \\
\text { others' } \\
\text { perspectives. }\end{array}$ & $\begin{array}{l}\text { Recognizes or } \\
\text { identifies } \\
\text { linguistic and } \\
\text { cultural } \\
\text { boundaries but } \\
\text { does little to } \\
\text { attempt to } \\
\text { cross them. }\end{array}$ \\
\hline
\end{tabular}




\begin{tabular}{|c|c|c|c|c|}
\hline Problem solving & $\begin{array}{l}\text { Recognizes } \\
\text { complex and } \\
\text { multiple } \\
\text { dynamics in the } \\
\text { community work } \\
\text { setting. } \\
\text { Responds } \\
\text { collaboratively } \\
\text { to issues that } \\
\text { arise } \\
\text { unexpectedly. } \\
\text { Adapts and } \\
\text { applies skills, } \\
\text { abilities, } \\
\text { theories, or } \\
\text { methodologies } \\
\text { gained in one } \\
\text { situation to new } \\
\text { situations to } \\
\text { solve difficult } \\
\text { problems or } \\
\text { explore complex } \\
\text { issues in flexible, } \\
\text { collaborative } \\
\text { ways. }\end{array}$ & $\begin{array}{l}\text { Recognizes the } \\
\text { complexity of the } \\
\text { community work } \\
\text { setting. Responds to } \\
\text { issues that arise } \\
\text { unexpectedly. } \\
\text { Considers more } \\
\text { than one } \\
\text { perspective when } \\
\text { attempting to solve } \\
\text { difficult problems } \\
\text { or explore complex } \\
\text { issues. }\end{array}$ & $\begin{array}{l}\text { Attempts to } \\
\text { respond to } \\
\text { issues that } \\
\text { arise } \\
\text { unexpectedly } \\
\text { and considers } \\
\text { more than one } \\
\text { perspective } \\
\text { when } \\
\text { attempting to } \\
\text { solve issues, } \\
\text { but may not do } \\
\text { so } \\
\text { successfully. }\end{array}$ & $\begin{array}{l}\text { Recognizes } \\
\text { issues and } \\
\text { does little to } \\
\text { respond, or } \\
\text { uses the } \\
\text { situation as a } \\
\text { reason to step } \\
\text { back from } \\
\text { productive } \\
\text { work. }\end{array}$ \\
\hline $\begin{array}{l}\text { Application and } \\
\text { analysis of } \\
\text { academic } \\
\text { knowledge }\end{array}$ & $\begin{array}{l}\text { Connects, } \\
\text { synthesizes, } \\
\text { critiques, and/or } \\
\text { extends } \\
\text { academic } \\
\text { knowledge } \\
\text { (facts, theories, } \\
\text { etc.) to the } \\
\text { execution and } \\
\text { interpretation of } \\
\text { community- } \\
\text { based work. }\end{array}$ & $\begin{array}{l}\text { Connects academic } \\
\text { knowledge (facts, } \\
\text { theories, etc) to the } \\
\text { execution and } \\
\text { interpretation of } \\
\text { community-based } \\
\text { work. }\end{array}$ & $\begin{array}{l}\text { Begins to } \\
\text { connect } \\
\text { academic } \\
\text { knowledge } \\
\text { (facts, } \\
\text { theories, etc.) } \\
\text { to execution } \\
\text { and } \\
\text { interpretation } \\
\text { of community- } \\
\text { based work. }\end{array}$ & $\begin{array}{l}\text { Begins to } \\
\text { understand that } \\
\text { academic } \\
\text { knowledge } \\
\text { (facts, theories, } \\
\text { etc.) is } \\
\text { connected to } \\
\text { community- } \\
\text { based work, } \\
\text { but may not } \\
\text { explicitly link } \\
\text { them based on } \\
\text { his/her } \\
\text { experience in } \\
\text { community- } \\
\text { based work. }\end{array}$ \\
\hline
\end{tabular}




\begin{tabular}{|c|c|c|c|c|}
\hline $\begin{array}{l}\text { Confianzal } \\
\text { relationship } \\
\text { building }\end{array}$ & $\begin{array}{l}\text { Cultivates } \\
\text { appropriate } \\
\text { relationships } \\
\text { with community } \\
\text { partners } \\
\text { grounded in } \\
\text { shared notions of } \\
\text { respect, trust, } \\
\text { and } \\
\text { collaboration. }\end{array}$ & $\begin{array}{l}\text { Forms appropriate } \\
\text { relationships with } \\
\text { community } \\
\text { partners. }\end{array}$ & $\begin{array}{l}\text { Begins to form } \\
\text { appropriate } \\
\text { relationships } \\
\text { with } \\
\text { community } \\
\text { partners. }\end{array}$ & $\begin{array}{l}\text { Recognizes } \\
\text { value of } \\
\text { forming } \\
\text { relationships } \\
\text { with } \\
\text { community } \\
\text { partners, but } \\
\text { may not } \\
\text { actually form } \\
\text { them. }\end{array}$ \\
\hline $\begin{array}{l}\text { Critical self- } \\
\text { awareness }\end{array}$ & $\begin{array}{l}\text { Student reveals } \\
\text { critical and } \\
\text { meaningful } \\
\text { interpretation of } \\
\text { lived and } \\
\text { observed } \\
\text { experiences in } \\
\text { the community } \\
\text { setting. } \\
\text { Student } \\
\text { embraces } \\
\text { complex, even } \\
\text { contradictory } \\
\text { understandings } \\
\text { of his/her place } \\
\text { in social } \\
\text { systems, } \\
\text { discourses, and } \\
\text { cultures. }\end{array}$ & $\begin{array}{l}\text { Student reflects on } \\
\text { and analyzes lived } \\
\text { and observed } \\
\text { experiences in the } \\
\text { community setting. } \\
\text { Student recognizes } \\
\text { complex } \\
\text { understandings of } \\
\text { his/her place in } \\
\text { social systems, } \\
\text { discourses, and } \\
\text { cultures }\end{array}$ & $\begin{array}{l}\text { Student } \\
\text { reflects on } \\
\text { lived and } \\
\text { observed } \\
\text { experiences in } \\
\text { the community } \\
\text { setting. } \\
\text { Student } \\
\text { recognizes } \\
\text { his/her place } \\
\text { in social } \\
\text { systems, } \\
\text { discourses, } \\
\text { and cultures. }\end{array}$ & $\begin{array}{l}\text { Student reports } \\
\text { on lived and } \\
\text { observed } \\
\text { experiences in } \\
\text { the community } \\
\text { setting with } \\
\text { little analysis } \\
\text { or reflection. } \\
\text { Student may } \\
\text { understand that } \\
\text { she/he plays } \\
\text { part in larger } \\
\text { social systems, } \\
\text { but may adopt } \\
\text { a simplistic } \\
\text { attitude } \\
\text { towards it, } \\
\text { ranging from } \\
\text { gratitude to } \\
\text { indifference to } \\
\text { sense of } \\
\text { superiority. }\end{array}$ \\
\hline
\end{tabular}




\section{Notes}

1. We prefer the term "community-based learning" over "service learning." Service learning implies an emphasis on what students "give" and what community members "receive." This perspective ignores the possibility of collaborative community projects, such as the oral history project described here, where community members were the "givers" of their experience and knowledge and university students were the "receivers." When quoting others, we follow the terminology each author employs.

2. We recognize the equally imperative question of community outcomes and their significance in developing ethical, sustainable, and productive community partnerships, and do not wish to minimize them here; rather, this study examines the outcomes for the university students with whom we spent the most time personally.

3. For a parallel in German, see Ter Horst and Pearce (2010).

4. The partnership between the Nabe and Drew has continued past the research project described here and includes student involvement in the ESOL program in CBL classes led by Drew faculty Sarah Wald in 2012, Elías Ortega-Aponte in 2014, and Elizabeth Kimball in 2015. Other students at Drew University have continued to work in the ESOL programs as volunteers, Civic Scholars, and interns, creating an ongoing, mutual partnership between the university and the center.

5. Students completed additional writing and in-class exercises related to their community experience in each class, but here we are focusing on the essays that students in both classes completed.

6. Two students in each class choose not to participate in the study.

7. One Spanish HL grew up speaking Dutch in addition to English and Spanish at home.

$\underline{8}$. This student also studied Italian at the college level.

9. One student in this category grew up hearing a limited amount of Italian, but for all practical purposes was monolingual in English and only participated in an Italian speech community on family trips abroad. Another student was an international adoptee to the United States and did not have the opportunity to speak her native language again until she began formal language study at the college level. While neither of these students are strictly English monolinguals, as a result of their experiences with language study and the ways their learning outcomes align with native English monolinguals, we have chosen to classify them as such.

10. Two students in the English class in the study did not report their previous levels of service and are not included in this analysis.

11. Students' writing has not been edited for the sake of authenticity. All names are pseudonyms.

12. When averaging students' scores for each of the five categories, they were assigned a zero if they did not address a particular category in their writing; this is represented by the raw score. The adjusted score removed students from the average whose essays did not address a particular category. We present both scores here because raw scores are indicative of what students choose to write about (or not) in their essays and the average scores are indicative of writing scores that did fit within a particular category. Both scores are presented when the raw and adjusted scores are different. 
13. Green (2003) even suggests that the long-standing reflection genre commonly assigned in CBL courses extends this reluctance to engage problematics of difference, and suggests assigning field observation and later analysis instead, so that students connect life experience with systematic injustice more directly through their writing assignments. Like our oral history project, Green sees her ethnographic assignments as "research in solidarity with the service site" (p. 293).

14. Titles of earlier publications in the field on language and community engagement are indicative of the perceived distance and difference between university and community partners: "Crossing the Border through Service-Learning (Tilley-Lubbs, 2004) and Construyendo Puentes (Building Bridges) (Hellebrandt \& Varona, 1999).

15. Velázquez (2015b) also develops this idea with respect to the different kinds of social capital HLs enact when reading and writing in Spanish in online environments.

16. Evidence of this action might be revealed in writing about attitude, for example, may come to cross-language community with a monolithic notion of language or language proficiency, or a model of language learning that privileges native or expert status over novice status, or a conviction of the inherent impossibility of cross-language communication.

17. "I am so lucky for what I have," "I've worked for what I have and others need to do the same" or "my grandparents learned English, so should Latino/a immigrants." 